\title{
Commentary: The HIV-Positive Resident: Questions and More Questions
}

Marguerite Blythe, MD

University of Cincinnati, Cincinnati Ohio

Follow this and additional works at: https://jdc.jefferson.edu/jeffjpsychiatry

Part of the Psychiatry Commons

Let us know how access to this document benefits you

\section{Recommended Citation}

Blythe, MD, Marguerite (1989) "Commentary: The HIV-Positive Resident: Questions and More Questions," Jefferson Journal of Psychiatry. Vol. 7 : Iss. 1 , Article 10.

DOI: https://doi.org/10.29046/JJP.007.1.009

Available at: https://jdc.jefferson.edu/jeffjpsychiatry/vol7/iss1/10

This Article is brought to you for free and open access by the Jefferson Digital Commons. The Jefferson Digital Commons is a service of Thomas Jefferson University's Center for Teaching and Learning (CTL). The Commons is a showcase for Jefferson books and journals, peer-reviewed scholarly publications, unique historical collections from the University archives, and teaching tools. The Jefferson Digital Commons allows researchers and interested readers anywhere in the world to learn about and keep up to date with Jefferson scholarship. This article has been accepted for inclusion in Jefferson Journal of Psychiatry by an authorized administrator of the Jefferson Digital Commons. For more information, please contact: JeffersonDigitalCommons@jefferson.edu. 


\title{
Commentary:
}

\section{The HIV-Positive Resident: Questions and More Questions}

\author{
Marguerite Blythe, M.D.
}

The resident physician who is infected with the human immunodeficiency virus (HIV) faces unique problems. In addition to the difficulties caused by a chronic and lethal disease, HIV-infected physicians-in-training face ethical, educational and practical problems that are unique to the interplay between residency training and the infection.

To date, physicians who have been found to be infected with HIV have faced public discrimination, many with devastating results. Dr. Hacib Aoun, a Venezulean-born cardiologist who contracted AIDS from a boy with leukemia while he was a resident at Johns Hopkins, overcame rumors about how he had contracted the disease only to be faced with possible deportation. Despite being married to a U.S. citizen, Dr. Aoun was confronted with an immigration law that stated that foreign citizens who have AIDS cannot become U.S. residents (1). Dr. Robert J. Huse was forced to close his Texas pediatrics practice when irate parents learned he had tested positive for HIV (2). Newspaper headlines from the November 16th issue of Today, an English newspaper, proclaimed "AIDS Doctor Who Died"; the paper provided a photograph of the doctor and a one-page report, noting that his wife and children were "in hiding" (3).

While the issue of patient safety has been raised with awesome regularity in these and other reports on physicians with AIDS, public hysteria usually centers around patients contracting AIDS from physicians. Despite numerous reports that casual contact does not spread AIDS (4), even health care professionals are often ignorant about AIDS and how it is transmitted (5). Few people would disagree with the American Medical Association position that a physician who knows that he or she is seropositive should not engage in any activity that creates a risk of transmitting the disease to others (6). However, fear of this disease is so intense, that what constitutes "safety" has sometimes been differently defined for AIDS than for other diseases, even more prevalent diseases such as Hepatitis B which can also have lethal consequences (7).

More recently, however, the safety issue has shifted to AIDS dementia. Infected physicians might fail to treat patients safely, according to this reasoning, not because of the possibility of infecting the patient but because the dementia could prevent the physician from practicing good medicine (3). As 
more research is done on AIDS dementia, it appears that subtle neuropsychological changes occur long before a full blown dementia can be detected. Sophisticated testing is required to detect these early changes, which involve executive functions of the brain such as the ability to integrate new information (8). Thus the question which is raised by those who oppose HIV-infected physicians practicing medicine is whether any brain change at all is acceptable in someone who works with patients.

In the best of all possible worlds, and in one where terror about AIDS did not exist, residents who are HIV-positive could share this information with supervisors who would then help residents monitor whether they were experiencing problems with learning that were caused by the disease, verses other problems common to all residents. Supervisors could help determine whether dementia or pseudodementia associated with depression might be complicating a resident's problems and at what point a sophisticated neuropsychological evaluation was needed. The resident would not, in this ideal world, be needlessly frustrated by treatable problems, and patients would not be subjected to care by physicians with impaired judgment due to organic causes.

But this is not an ideal world. Individuals often receive inhumane treatment when HIV-positive status is revealed. Confidentiality is such an issue that at one large medical center, residents who have accidental needle sticks or who wonder about their HIV status for other reasons are told by faculty members to get tested at the health department, rather than use medical center laboratories. The health department in this particular city submits tests to laboratories by number, not name, and only a few counselors have access to files that enable them to translate numbers to names. At the medical center, lab slips pass through many hands before they finally wind up in a medical chart. Often, no attempt is made to disguise the report once it is in the chart.

One resident who had engaged in high risk behaviors in the past confided to this author that he did not intend to get tested. He had changed his behavior and there was nothing to be gained from knowing whether or not he was HIV-positive. But there was a lot to lose if anyone should find out. If he wasn't tested, no one could know the results. Whether there is anything to be gained from knowledge of one's HIV-status might be argued now that AZT is being used earlier and earlier in the course of the infection. A few well-publicized horror stories are enough, however, to make anyone wonder about the value and the cost of such knowledge.

But what are the questions that an individual resident who knows that he or she is HIV-positive needs to ask?

AIDS dementia needs to be taken very seriously. People who are becoming demented are poor judges of this, regardless of their professional training. However, declarations that anyone who is HIV-positive should not practice medicine presuppose that AIDS dementia is somehow different from every other organic process that can happen to a physician. Physicians, like everyone else, get many diseases that can potentially affect their mentation. Many times 
the physician is the last to realize that a problem exists. If all physicians who might get brain tumors, or other central nervous system diseases, or who might come down with organic problems due to future substance abuse, or auto-immune problems, or infections, are eliminated from practicing medicine, who would be left? Even if physicians who are known to have problems that can cause organic confusion were the only ones eliminated from practicing medicine, wholesale discrimination would have to occur. Is that what we want?

We cannot say there is zero risk to patients from physicians who might get AIDS-related dementias and be unaware of their problems; how much risk is too much?

Society hasn't been good at answering this ethical question. Terror and phobic responses often get in the way of reasoning. The resident is left to answer this question for him or herself. This may not be the way it should be. Given the dire consequences of being honest about HIV-status (consequences which are often unfair, cruel, and unethical) one must ask whether at present society can give better answers than the individuals themselves.

Educational issues can cause the resident problems in ways unrelated to dementia, however. Residencies are both educational institutions and work sites. Being on-call provides the resident with a wealth of experience, but it is also hard work. Most residencies do not have the luxury of extra residents to take over call if one resident gets seriously ill. Residents must cover for each other. At what point does decreasing work hours cause a resident's education to suffer? At what point does covering for ill residents cause the covering residents' educations to suffer? At what point do anger and guilt over covering and being covered for interfere with everyone's education, not to mention everyone's ability to deal with stress, with work, with family and with patients?

Residents and graduate physicians do not comprise the only group that faces dilemmas when HIV infection, or indeed any other chronic condition, interacts with professional accountability. Because residency training is an intense experience that demands long hours and more responsibility than many other forms of education, and because it is an odd combination of education, apprenticeship and work, residency training brings a peculiar set of circumstances to bear on being HIV-positive. At best, the resident is faced with many decisions that his or her predecessors and teachers have neither faced nor solved. At worst, the training experience can make a tragic disease unbearable.

What we know about AIDS has changed so rapidly that what we told patients a year ago may no longer be true today. Questions that today have no answers, tomorrow may be simplistic. Between the time of writing this paper and the time of presenting and publishing it, things may have changed. Even the questions asked may have to be revised. Is the HIV-infected resident a case of the impaired physician? Who decides? How do we protect the individual and protect society at the same time? How much caution really is needed? What is ethical to demand of a person with HIV? What should such a person demand of him or herself? These questions, and others, need to be asked if potential 
answers are to be found. When we arbitrarily decide which questions can and cannot be asked, when we decide what can and cannot be talked about, we not only censor discussion, we edit possible solutions.

AIDS is a lethal infectious disease. Terror all too often dictates what is discussed about this disease and which conclusions are drawn. Despite the importance of asking questions and trying to find answers, despite the importance of avoiding censorship, questions can be cruel as well as useful; they can be rhetorical as well as open-ended; they can be used for harmful purposes as well as good. Questioning needs to be done in such fashion that terror is not allowed to dictate answers. Given the fear that surrounds any unpredictable plague (9), answers to never-before-asked questions will not come easily. We should not only be cautious in deciding whether questions have been adequately answered, we must not allow ourselves to be easily persuaded that the right questions have been asked.

\section{REFERENCES}

1. Scheier R: Immigration rule magnifies grief for MD with AIDS. Am Med News 3:20-21, Mar 4, 1988

2. Gallo N: HIV-positive doctors prognosis: fear and uncertainty. New Physician $37: 28-32,1988$

3. Ayd FJ: Patient Safety? doctors with HIV. The Psychiatric Times 5(1):32-33, 1988

4. Lifson AR: Do alternate modes of transmission for human immunodeficiency virus exist? a review. JAMA 259:1353-1356, 1988

5. Ignorance about AIDS, homophobia still strong among health professionals. Psychiatric News pp 11, 25, June 171988

6. AMA Council on Ethical and Judicial Affairs: Ethical issues involved in the growing AIDS crisis. JAMA 259:1360-1361, 1988

7. Hagen MD, Klemens B, Pauker SG: Routine preoperative screening for HIV: does the risk to the surgeon outweigh the risk to the patient? JAMA 259:1357-1359, 1988

8. Krikorian R, Liang W, Kay J: Grand Rounds: new research on AIDS from the University of Cincinnati. March 1988

9. Shenson D: When fear conquers: a doctor learns about AIDS from leprosy. New York Times Magazine. pp 34-38, 48, Feb 28, 1988 